\title{
Scale insects (Hemiptera: Coccoidea) on oriental spruce
}

\author{
Selma Ülgentürk ${ }^{\mathrm{a}, *}$ (i), Mustafa Özdemir ${ }^{\mathrm{a}}$ (i)
}

\begin{abstract}
Oriental spruce (Picea orientalis (L.) Link) is an important forest trees and forms pure or mixed stands in the Black Sea region, Turkey. It is also utilized as an ornamental plant in gardens and parks. To determine coccoid species infesting oriental spruce in Giresun Province, forest, parks and gardens located in the city center of Giresun was surveyed. Results revealed four scale insects: namely, Coccus hesperidum L., Physokermes piceae Schrank (Coccidae), Dynaspiotus britannicus (Balachowsky) (Diaspididae), and Phenacoccus piceae Löw (Pseudococcidae) which is a new record for the Turkish fauna. Oriental spruce mealybug P. piceae was found to be associated with Nephus caneparii Fürsh \& Uygun (Coleoptera; Coccinellidae), Cardiastethus nazarenus Reuter (Hemiptera: Anthocoridae) and Sympherobius pygmaeus (Rambur) (Neuroptera: Hemerobiidae) and Coccidiphila gerasimovi (Danilevsky) (Lepidoptera: Cosmopterigidae). Important morphological characters of oriental spruce mealybug were presented, and additionally, information on biology, distribution and damage of scale insects feeding on oriental spruce has been given based on the literature.
\end{abstract}

Keywords: Spruce mealybug, Phenacoccus piceae, Picea orientalis, Predators, Coccidiphila gerasimovi, Giresun

\section{Doğu ladininde zararlı kabuklubit türleri (Hemiptera: Coccoidea)}

\begin{abstract}
Özet: Türkiye'de Karadeniz ormanlarında saf veya karışık ormanlar kuran doğu ladini Picea orientalis (L.) Link), önemli bir orman ağacı olması yanında estetik görüntüsü nedeniyle park ve bahçelerde süs bitkisi olarak faydalanılmaktadır. Giresun ili merkezi-orman, park ve bahçelerinde yapılan incelemede, doğu ladini üzerinde Coccus hesperidum L. Physokermes piceae Schrank (Coccidae), Dynaspiotus britannicus (Balachowsky) (Diaspididae) ve Phenacoccus piceae Löw (Pseudococcidae) türlerinin zararlı olduğu tespit edilmiştir. Türkiye faunası için yeni bir kayıt olan $P$. piceae (Ladin unlubiti) morfolojik özellikleri ile tanıtılmıştır. Bu unlubit ile Nephus caneparii Fürsh \& Uygun (Coleoptera: Coccinellidae), Cardiastethus nazarenus (Hemiptera: Anthocoridae), Sympherobius pygmaeus (Rambur) (Neuroptera: Hemerobiidae) ve Coccidiphila gerasimovi (Danilevsky) (Lepidoptera: Cosmopterigidae) türlerinin beslendiği saptanmıştır. Ladin unlubitinin önemli morfolojik karakterlerinin yanı sıra, tüm türlerin biyolojisi, yayılışı, zararı hakkında literatüre dayalı bilgi verilmiştir.

Anahtar kelimeler: Ladin unlubiti, Phenacoccus piceae, Picea orientalis, Avc1, Coccidiphila gerasimovi, Giresun
\end{abstract}

\section{Introduction}

Oriental spruce (Picea orientalis (L.) Link) (Pinaceae) is an important timber tree in the Caucasus and Black Sea Region where it forms extensive pure stands or mix stand associated with Abies nordmanniana (Stev) (Pinaceae) in Turkey. It is vertically distributing from 600-2050 meters. It is a shade-tolerant, moisture demanding tree and usually grows on brown forest soils and lies from Black Sea coast to the Central Greater Caucasus. It can grow to $40-45 \mathrm{~m}$ in height and $1.5-2.5 \mathrm{~m}$ in diameter. The wood of oriental spruce is of good quality, and have been used for many purposes including carpentry, construction, flooring, furniture making, and musical instruments (Farjon, 2013). Moreover, oriental spruce is an ornamental tree for parks and gardens in Turkey as many European countries and in the USA (Arslan and Çelem, 2001; Farjon, 2013).

Scale insects (Hemiptera: Coccoidea) are sap feeders having piercing and sucking mount parts and are small, cryptic plant parasites. Many species are important agricultural, forestry pests and most of them are invasive in the World (Kosztarab and Kozár, 1988; Williams, 2004). Scale insects feed on conifers, causing slightly or unsightly discoloration and deformation of needles, premature needle fall, reduced shoot growth, honeydew secretion that encourages the growth of sooty molds, interfered photosynthesis, and even death of the tree (Johnson \& Lyon, 1994). On the other hand, honeydew is an important food source for insects (ants, bees, etc.) many birds and mammals (Durovic and Ülgentürk, 2014). They live mostly sedentary on plants.

In Turkey scale insects on conifers were investigated by Çanakçığlu (1977), Selmi (1979), Ülgentürk and Çanakçıŏlu, (2004); Ülgentürk et al. 2012a,b; Ülgentürk et al. 2019a,b). The major scale insect of spruce trees are Physokermes piceae (Schrank) (Hemiptera: Coccidae) in urban areas in Turkey. It is very common and harmful pest on ornamental spruce trees in urban areas of Ankara, İstanbul and Eskişehir provinces (Turguter and Ülgentürk 2007; Kaydan et al. 2013). P. piceae, a major pest for European spruce trees as well, cause needle weight loss and reduced offshoot growth (Gedminas et al., 2015).

\footnotetext{
$\bowtie$ a Ankara University, Department of Plant Protection, 061110 Dişkapı, Ankara, Turkey

b Ministry of Agriculture and Forestry, Directorate of Plant Protection Central Research Institute, Ankara, Turkey 
Physokermes hemicyrphus (Dalman) (Hemiptera: Coccidae) is also another important pest on oriental spruce in Europe (Kosztarab and Kozár, 1988). On the other hand, it is accepted as a useful insect for honeydew honey production in Europe (Kunkel, 1997). Marchalina caucasica Hadzibeyli (Hemiptera: Marchalinidae) was recorded on $P$. orientalis and A. nordmanniana in Black Sea region, Turkey (Ülgentürk et al., 2019b) and Picea engelmanni Parry ex Engelm. in Georgia (Hadjzibeyli, 1969).

In this study, it is aimed to determine scale insects on oriental spruce in the natural forest and urban areas of Giresun, Turkey. Biology, distribution and host plants of the scale insects feeding on oriental spruce and a new record species of Phenacoccus are given.

\section{Material and methods}

Scale insects are collected directly from the needle of oriental spruces $\left(P\right.$. orientalis) in Çıtlakkale $\left(40^{\circ} 54^{\prime} 28.5^{\prime \prime} \mathrm{N}\right.$ $\left.38^{\circ} 21^{\prime} 47.9^{\prime \prime E}, 1 \mathrm{~m}\right)$, Castle of Giresun $\left(40^{\circ} 54^{\prime} 27.8^{\prime \prime} \mathrm{N}\right.$ $\left.38^{\circ} 21^{\prime} 47.5^{\prime \prime E}, 300 \mathrm{~m}\right)$, Giresun/ Keşap $\left(40^{\circ} 53^{\prime} 00.48^{\prime \prime} \mathrm{N} 38^{\circ}\right.$ 34'36.28"E, $502 \mathrm{~m}$ ), Giresun/Bicik (Çamalan) $\left(40^{\circ} 39^{\prime} 04.3^{\prime \prime N} 38^{\circ} 18^{\prime} 23.8^{\prime \prime} 1826 \mathrm{~m}\right)$; Giresun/ Kulakkaya $\left(40^{\circ} 41^{\prime} 51.8^{\prime \prime N} \quad 38^{\circ} 20^{\prime} 22.16^{\prime \prime} \mathrm{E} 1640 \mathrm{~m}\right)$. Specimens were slide-mounted according the procedure described by Kosztarab and Kozár (1988). The identification of species is made according to Balachowsky (1948), Williams and Kosztarab (1972), Kosztarab and Kozár (1988), and Danzig (2006). The data about distribution and host plants of scale insects were used from Scalenet (Garcia et al., 2016). In order to obtain natural enemies of scale insect, the sampled branches are placed in glass cylinders. Scales and their natural enemies, i.e. predators found within their colonies, are reared there. The adult predators were diagnosed by experts.

\section{Results and discussion}

A total 4 species belonging to Coccidae, Diaspididae and Pseudococcidae are found on oriental spruce in Giresun.

\section{Coccus hesperidum L. Soft brown scales (Coccidae)}

Material Examined: Giresun (Centrum), 5 qq, Picea orientalis, 26.vi.2018.

Female of $C$. hesperidum on oriental spruce needle is narrow, more reddish in color in comparison to those other females feeding on other host plants (Figure 1a). It is cryptic, not easy to see, secretes large amounts of honeydew and the adjoining foliage becomes heavily coated with sooty mold. Soft brown scale is cosmopolite and polyphagous species. It is an important pest of citrus and ornamental plants in Turkey (Kaydan et al., 2013). It was recorded previously on Abies concolor (Gordon), A. nordmanniana (Steven), Cedrus atlantica (Endl.), Cedrus libani A. Richard, Pinus pinaster (Aiton), P. pineae L. (Pinaceae), Taxus baccata L. (Taxaceae) (Selmi ,1979; Ülgentürk et al., 2012a,b). It was founded on Abies sp., Cedrus sp., Picea glauca (Moench) Voss, Pinus sp., P. caribaea Morelet, $P$. halepensis Miller, P. nigra, $P$. radiata D. Don, P. sylvestris L., Tsuga canadensis (L.) Carrière in different countries (Garcia et al., 2016).
Physokermes piceae (Shcrank) Spruce bud scale (Coccidae)

Material Examined: Giresun (Centrum), $3 q q, 7 \mathrm{~N}_{1}, P$. orientalis, 26.vi.2018; Castle, 2ㅇ, 19.x.2018

It has a moderate population on oriental spruce. Adult female of spruce bud scale is kidney-shaped, shiny brown. Young female is pinkish-yellow. Females occurs at the base of twig forkings and at base of needles. It is one of the important pests of ornamental spruce such as P. abies (L.) $(P$. excelsa), $P$. orientalis, $P$. pungens, in urban areas of Ankara, Eskişehir and İstanbul (Çanakçığlu, 1975; Ülgentürk et al., 2019a). Turguter and Ülgentürk (2006) determined that spruce bud scale overwintered as second nymph stage and has one generation in a year in Ankara.

Dynaspidiotus britannicus (Balachowsky) The holly scale (Diaspididae)

Material Examined: Giresun/Bicik, 3 우, P. orientalis 18. vi.2017; Giresun/Kulakkaya, 3 우, P. orientalis, 18. vi.2017; Giresun (Centrum), 7 우, $P$. orientalis, 26.vi.2018;

Female scale circular or almost so, moderately convex, dusky ochreous colored with a broad smoky-brown central zone; exuviae central, those of the larvae dark yellow or dull orange. The holly scale was recorded from several countries in the Palearctic and Nearctic regions. In Turkey, it was reported as an important cedar pest in urban areas of Ankara and Kastamonu provinces (Kaydan et al., 2014). It has two generations in a year and overwinters as second stage nymph in Ankara (Ayhan and Ülgentürk, 2011). It is described as a minor pest of olive in Mediterranean countries (Argyriou, 1990), and of palms and ornamentals in other various countries (Zahradnik, 1990).

Phenacoccus piceae Löw Spruce mealybug
(Pseudococcidae)

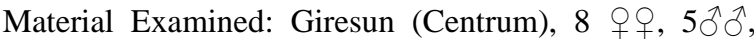
$4 \mathrm{~N}_{2}, 5 \mathrm{~N}_{1} P$. orientalis, 26.vi.2018; Giresun/Bicik, 2 우, $P$. orientalis, 17.x.2018

Adult female is long oval, pink, up to $2.5 \mathrm{~mm}$ long and $1.7 \mathrm{~mm}$ wide. Body covered with white waxy powder. Ovisac is white and cottony (Figure 1b,c). All of the stages is occurred on the needle under the twinges. Antennae 9 segmented. Legs well developed, usually slender, often with denticle on claw. Cerarii 6-7 pairs, 4 pairs on the head, 3 pairs on apex of abdomen, anal lob cerarius with 2 conical setae, 1-2 short setae and 15-20 trilocular pores. Anal lob moderately developed. $\mathrm{C}_{1}-\mathrm{C}_{3}$ are not borne on sclerotized plates (Kosztarab and Kozár, 1988).

$P$. piceae is distributed Palearctic region where its hosts grow. A. nordmanniana, Picea spp., $P$. abies $P$. brachytyla Franch, $P$. obovata Ledeb., $P$. orientalis, $P$. schrenkiana Fisch. \& C.A.Mey. (Pinaceae) and Taxus sp. (Taxaceae) were stated as its host plants. It was observed in very large population on twigs of oriental spruce in Giresun (Figure 1b,c). Infested oriental spruce trees looked like sunburned. Spruce mealybug is found mostly at sea level, and only two females natural forest in Giresun. However, according to Kosztarab and Kozár (1988) it was often found in mountains at high elevations. $P$. piceae has 1-3 generations in a year depending on climatic conditions. Females lay about 150 eggs and overwinter as females, 
mostly as third instars, whereas males overwinter as pupae, often under bark flakes or in old galls produced by aphids. It was reported as an occasional pest of physiologically weakened ornamental spruce trees (Zahradnik, 1990).

Predators of spruce mealybug

Nephus caneparii Fürsh \& Uygun, 1980 (Coleoptera: Coccinellidae)

Material Examined: Giresun (Centrum), 4 adults, Picea orientalis, 26.vi.2018.

It is a common predator recorded in cherry, and olive orchards in Aegean, Mediterranean, and Southeastern Anatolia Region in Turkey (Tezcan and Uygun, 2003). It is recorded a predator of Pseudococcus cryptus Hempel (Hemiptera: Pseudococcidae) on Citrus in Hatay, Turkey (Yiğit and Telli, 2013).

\section{Cardiastethus nazarenus Reuter (Hemiptera: Anthocoridae)}

Material Examined: Giresun (Centrum), 12 adults, Picea orientalis, 26.vi.2018.

This predator was reported feeding on many scale insects including Pseudococcus cryptus Hempel (Hemiptera: Pseudococcidae) (Yiğit and Telli, 2013) and $M$. hellenica (Ülgentürk et al., 2013) in Turkey.

Sympherobius pygmaeus (Rambur) (Neuroptera: Hemerobiidae)

Material Examined: Giresun (Centrum), 10 adults, Picea orientalis, 26.vi.2018.

$S$. pygmaeus was determined as a predator of Phenacoccus aceris (Signoret), Planococcus ficus (Signoret), and on $P$. vovae (Nasonov) (Hemiptera: Pseudococcidae) in Ankara (Kaydan et al. 2006).
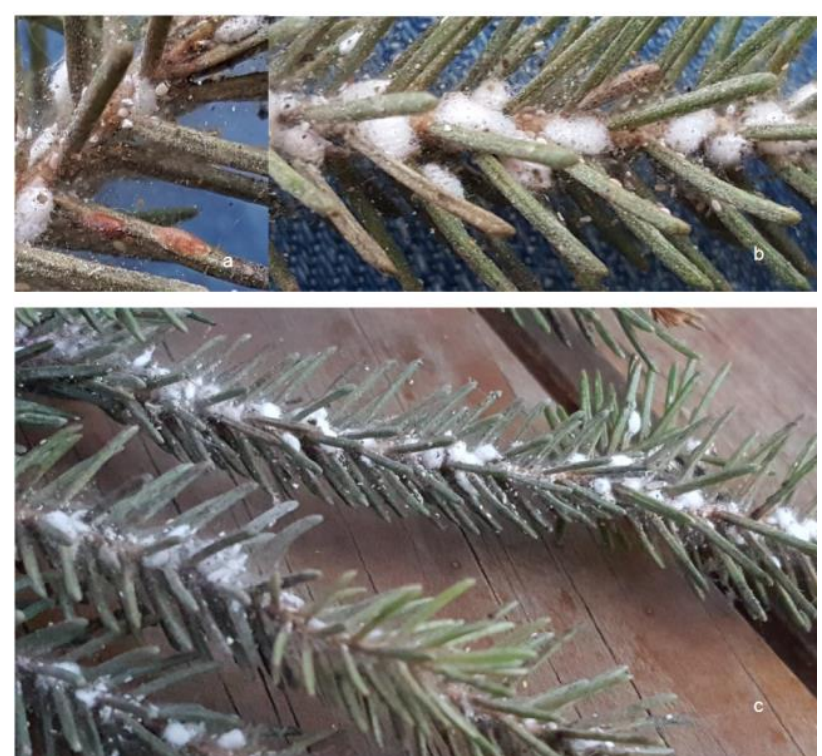

Figure 1. Coccus hesperidum (a) and Phenacoccus piceae $(b, c)$ on oriental spruce
Coccidiphila gerasimovi (Danilevsky) (Lepidoptera: Cosmopterigidae)

Material Examined: Giresun (Centrum), 4 adults, Picea orientalis, 16.vii.2018.

C. gerasimovi larvae were found under the colonies of oriental mealybug individuals. Previously $C$. gerasimovi was reported in a checklist of Lepidoptera of Turkey without information of location and host insect by Kemal and Kocak (2009). According to Koster and Sammut (2006), the larvae of $C$. gerasimovi feed on the eggs of Coccidae. The adults fly from early March to October, probably in more than one generation. It was a known predator of Spharolecanium prunastri (Fonscolombe) (Hemiptera: Coccidae) (Kosztarab and Kozár, 1988).

According to these results, $N$. caneparii, $C$. nazarenus, $S$. pygmaeus and $C$. gerasimovi were determined for the first time as predators of oriental mealybug. As a result, four scale insects (2 Coccidae, 1 Diaspididae and 1 Pseudococcidae) on oriental spruce were found that feed on needle and on young shoots of oriental spruce. $C$. hesperidum and Physokermes piceae are found only urban areas. Interestingly, a large population of spruce mealybug is observed on oriental spruce trees in urban areas unlike natural forest of Giresun. This result shows that the natural balance is still preserved in natural forests. However, it must be kept in mind that forest trees and urban trees are intertwined and that pests can be contaminated under favorable conditions. Biology, population dynamics and natural enemies of scale insects need to be studied to develop effective control methods.

\section{Acknowledgements}

The author wish to thank Prof. Dr. Nedim Uygun (University of Çukurova), Dr. Gülten Yazıcı (Directorate of Plant Protection Central Research Institute) and Dr. Ferenc Szentkirály (Plant Protection Institute, Hungarian Academy of Sciences) for the determination of Coccinellidae, Anthocoridae and Hemerobiidae species respectively. The author is grateful to Directorate of Forestry of Giresun for help and hospitality during this study.

The article was presented as poster in VII. Plant Protection Congress, 14-17 November 2018, Muğla.

\section{References}

Argyriou, L.C., 1990. Olive. In: Rosen, D. (Ed.), Armored Scale Insects, Their Biology, Natural Enemies and Control. World Crop Pests 4B. Elsevier, Amsterdam, pp. 579-583.

Arslan, M., Çelem, H., 2001. Exotic Trees and Plants of Ankara. Scientific and Technical Research Council of Turkey, TARP Publications, Ankara.

Ayhan, B., Ülgentürk S., 2011. Phenology of Dynaspidiotus britannicus (Newstead) (Hemiptera: Diaspididae) on the cedar in Ankara. In: Procedings of the 4th Plant Protection Congress of Turkey, 2011 Kahramanmaraş, Turkey, p.38.

Balachowsky, A.S., 1948. Les cochenilles de France, d'Europe, du nord de l'Afrique et du bassin Méditerranéen. IV. Monographie des Coccoidea, classification - Diaspidinae (Premiere partie). Entomologie Appliquée Actualités Scientifiques et Industrielles 1054: 243-394.

Farjon, A., 2013. Picea orientalis. The IUCN Red List of Threatened Species. http://dx.doi.org/10.2305/IUCN.UK.2013RLTS.T42332A2973275.en. 
Çanakçıŏlu, H., 1977. Türkiye 'de Orman Ağaçları ve Ağaççılarında Zarar Yapan Coccoidea (Hom.) Türleri Üzerinde Araştırmalar (Sistematik-Yayılış-Konukçu-Biyoloji), İstanbul Üniversitesi, Orman Fakültesi Yayınları: 2322, İstanbul.

Danzig, E.M., 2006. Mealybugs of the genus Phenacoccus Ckll. (Homoptera, Pseudococcidae) in the fauna of Russia and adjacent countries. II.. Entomological Review, 86(2): 197-227.

Durovic, G., Ülgentürk, S., 2014. Honeydew. Bulletin of Turkish Entomology, 4(2):121-137.

García, M. M., Denno, B.D., Miller, D.R., Miller, G.L., Ben-Dov, Y., Hardy, N.B., 2016. ScaleNet: A literature-based model of scale insect biology and systematics. Database. doi: 10.1093/database/bav118. http://scalenet.info.

Gedminas, A., Lynikienè, J., Marciulynas, A., Povilaitienè, A., 2015. Effect of Physokermes piceae Schrank on shoot and needle growth in Norway spruce stands in Lithuania. Baltic Forestry, 21:162-169.

Hadzibejli, Z.K., 1969. On Marchalina caucasica, sp. n. (Homoptera, Coccoidea) from the Caucasus. Entomological Review, 48: 391-398.

Johnson, W.T., Lyon, H.H., 1994. Insects that feed on trees and shrubs second edition. Cornell University press, London.

Kaydan, M. B., Ülgentürk, S., Erkılıç, L., 2013. Checklist of Turkish Coccoidea (Hemiptera: Sternorryncha) species. Bulletin of Turkish Entomology, 3: 157-182.

Kaydan, M. B., Ülgentürk, S., Özdemir, I., Ulusoy, M.R., 2014. Coccoidea (Hemiptera) species in Bartın and Kastamonu Provinces. Bulletin of Plant Protection, 54 (1): 11-44.

Kaydan, M.B., Kılınçer, N., Uygun, N., Japoshvili G., Gaimari, S., 2006. Parasitoids and Predators of Pseudococcidae (Hemiptera: Coccoidea) in Ankara, Turkey. Phytoparasitica, 34(4):331-337.

Kemal, M., Koçak, A., 2009. Revised Checklist of the Lepidoptera of Turkey. PRIAMUS Serial Publication of the Centre for Entomological Studies Ankara. Supplement 17, 254 pp.

Koster, S.C., Sammut, P., 2006. Faunistic notes on Momphidae, Batrachedridae, Stathmopodidae and Cosmopterigidae from the Maltese Islands. Nota Lepidopterologica, 29(1/2):49-63.

Kosztarab, M., Kozár, F., 1988. Scale Insects of Central Europe. Akademiai Kiado. Budapest Hungary.

Kunkel, H., 1997. Scale Insect Honeydew as Forage for Honey Production. In: Ben-Dov,Y., Hodgson, C.J., (Eds.), Soft Scale Insects - Their Biology, Natural Enemies and Control, Vol. 7A, Elsevier, Amsterdam, pp. 291-302.
Selmi, E., 1979. The Research on harmful Coccoidea (Hemiptera) Species on Coniferous tree in the Marmara Region. Journal of Istanbul University Faculty of Forestry. Serial: A, 29: 92- 127.

Turguter, S., Ülgentürk, S., 2006. Physokermes piceae (Schrank) (Yumrulu Ladin Koşnili) (Hemiptera; Coccidae)'nin biyolojik özellikleri. Tarım Bilim Dergisi, 12:44-50.

Tezcan, S., Uygun, N., 2003. Evaluation of the Coccinellidae (Coleoptera) fauna of ecologically managed cherry orchards in İzmir and Manisa Provinces of Turkey. Journal of Turkish Entomology, 27(1): 73-79

Ülgentürk, S., Çanakçıoğlu, H., Toper, A., 2004. Scale insects of the conifer trees in Turkey and their zoogeographical distribution. Journal of Pest Sciences, 77: 99-104.

Ülgentürk, S., Şahin, Ö., Ayhan, B., Sarıbaşak, H., Kaydan, M.B., 2012a. Scale insects species of Taurus cedar in Turkey. Turkish Journal of Entomology, 36: 113-121.

Ülgentürk, S., Evren, N., Ayhan, B., Dostbil, Ö., Dursun, O., Civelek, H.S., 2012b. Scale insect (Hemiptera: Coccoidea) species on pine trees of Turkey. Turkish Journal of Zoology, 36: 623-636.

Ülgentürk S., Szentkirályi F., Uygun N., Fent M., Gaimari S.D., Civelek H.S., Ayhan B., 2013. Predators of Marchalina hellenica Genn. (Hemiptera: Marchalinidae) on pine forest in Turkey. Phytoparasitica, 41(2):529-537

Ülgentürk, S., Özdemir, I., Muştu, M., Dostbil Ö., Erbaş, C., 2019a. Pest species of Aphidomorpha and Coccomorpha (Hemiptera) on Conifers urban areas of Ankara Turkey. Munis Entomology \& Zoology, 14 (1): 51-61.

Ülgentürk, S., Özdemir, I., Cosic, B., Kurnaz A.Ö., İpek A., Sorkun K., 2019b. Honeydew producing insects and their potential honeydew honey in Turkey. The 3rd International Symposium on EuroAsian Biodiversity 05-08 July 2017, Minsk - Belarus, p. 71 .

Williams, D.J., 2004. Mealybugs of Southern Asia. The Natural History Museum Kuala Lumpur: Southdene SDN. BHD.

Williams, D.J., Kosztarab, M., 1972. Morphology and systematics of the Coccidae of Virginia with notes on their biology (Homoptera: Coccoidea). Research division Bulletin, 74, Virginia.

Yiğit, A., Telli, S., 2013. Hatay ili turunçgillerinde zararlı Pseudococcus cryptus Hempel (Hemiptera: Pseudococcidae) 'un yayılışı, konukçuları ve doğal düşmanları. Turkish Journal of Entomology, 37(3):359-373.

Zahradnik, J., 1990. Forest: conifers. In: Rosen, D. (Ed.) Armored scale insects: Their biology, natural enemies and control, 4B. Elsevier, Amsterdam, pp. 633-644. 